\title{
Associação Brasileira de Ligas Acadêmicas de Oftalmologia: perspectivas e desafios
}

\author{
Acadêmicos: Juliana Mika Kato, Gabriel de Paula Albuquerque, Carolina Oshiro Yeh, Marina \\ Fonseca Resende, Marcela Feltrin de Barros \\ Orientadores: André Luis Portes, Pedro Carlos Carricondo
}

Introdução: A Associação Brasileira de Ligas Acadêmicas de Oftalmologia (ABLAO) é uma entidade acadêmica com o intuito de promover a integração científico-social de estudantes de Medicina interessados na especialidade. Criada em 2013 durante o I Encontro Nacional das Ligas Acadêmicas de Oftalmologia, a ABLAO tem estabelecido vínculo com ligas de diversas regiões do país, sendo atualmente 30 ligas cadastradas de 10 Estados.

Objetivo: Apresentar e divulgar a ABLAO e suas atividades.

Atividades: É missão da ABLAO a ampla difusão de conhecimento e a constante atualização de seus membros a respeito das mudanças evolutivas correntes no cenário oftalmológico. Assim como outras atividades de extensão universitária, baseia-se no tripé Ensino-Pesquisa-Extensão. No primeiro quesito, promove aulas e discussões quinzenais centradas em temas variados previamente escolhidos pelos acadêmicos por meio da parceria com a Sociedade Brasileira de Lentes de Contato, Córnea e Refratometria (SOBLEC); na base Pesquisa, busca a ampliação da produção científica dos graduandos por meio de divulgação de projetos de sucesso durante os encontros oficiais e do desenvolvimento de projetos multicêntricos; como Extensão, auxilia a promoção de saúde através de mídias digitais com vídeos sobre saúde ocular para a população geral, também em conjunto com a SOBLEC. O Encontro oficial dos membros ocorre anualmente como parte do Congresso da Sociedade Brasileira de Oftalmologia (SBO). O Encontro, portanto, é aberto a todos os médicos participantes deste Congresso. Discute-se a estrutura da liga, projetos de sucesso, há troca de experiências e incentivo e apoio à criação de outras ligas.

Organização e estrutura: Cada Liga indica um a dois representantes para compor a Diretoria da ABLAO. Tais representantes são responsáveis por ministrar uma palestra no Encontro das Ligas e por divulgar o evento nas dependências de sua faculdade. A Diretoria se comunica com o presidente do Congresso da SBO e com a empresa administrativa para oficializar o programa do Encontro.

Resultados: A ABLAO tem tido expressivas conquistas desde sua criação, como o crescente número de participantes no Encontro Nacional das Ligas Acadêmicas de Oftalmologia. Na primeira edição estiveram presentes representantes de 5 faculdades nacionais, já na segunda, houve aumento significativo para 23. Hoje a associação prevê 30 ligas no III Encontro. O Jornal Brasileiro de Oftalmologia tem acompanhado o progresso do evento com constantes publicações a respeito das conquistas da associação frente ao universo oftalmológico.

Discussão, Desafios e Perspectivas: A formação de associações entre ligas de diferentes instituições do país é uma tendência nas mais variadas especialidades dentro da Medicina, ilustrando o contato precoce e a troca de experiências bem sucedidas entre os acadêmicos com as diferentes áreas da profissão. Os eventos nacionais têm papel fundamental na difusão de ideias inovadoras e projetos pioneiros desenvolvidos e compartilhados entre as ligas, além de contribuir para o fortalecimento das ligas recém criadas proporcionando uma continuidade desse instrumento social e de ensino. O ato de reunir representantes de diferentes regiões do país é um desafio para a ABLAO que vem sendo superado com a utilização frequente de redes sociais e mídias digitais. 